\title{
Expression and purification of TAT-fused carbonic anhydrase III and its effect on C2C12 cell apoptosis induced by hypoxia/reoxygenation
}

\author{
Xiliang Shang', Yuanyuan Bao², Shiyi Chen ${ }^{1}$, Huimin Ren ${ }^{3}$, He Huang 3 , Yunxia $\mathrm{Li}^{1}$
}

1Department of Sports Medicine, Huashan Hospital, Fudan University, China 2Department of Endocrinology and Metabolism, Huashan Hospital, Fudan University, China

3Institute of Neurology, Fudan University, Shanghai, China

Submitted: 31 July 2011

Accepted: 24 January 2012

Arch Med Sci 2012; 8, 4: 711-718

DOI: 10.5114/aoms.2012.30295

Copyright (c) 2012 Termedia \& Banach

\author{
Corresponding author: \\ Shiyi Chen \\ Department \\ of Sports Medicine \\ Huashan Hospital \\ Fudan University \\ 12 Wu Lu Mu Qi Road \\ 200040 Shanghai, China \\ Phone: 86-21-52888255 \\ Fax: 86-21-62496020 \\ E-mail: sychen0011@163.com; \\ sx100702@126.com
}

\begin{abstract}
Introduction: Carbonic anhydrase III (CAIII) is remarkably abundant in slow skeletal muscles. It has multiple biological activities which could dissipate or resist some fatigue-related substances. In this study, we purified trans-activating transcriptional activator (TAT) fused CAIII protein and investigated its effect on C2C12 cell apoptosis induced by hypoxia/reoxygenation.

Material and methods: The CAIII and TAT-CAlll genes were constructed, cloned into plasmid pET28a and expressed in Escherichia coli BL21 (DE3). The fusion proteins were purified with a nickel-nitrilotriacetic acid affinity chromatography column and then verified by Western blot and phosphatase activity staining subsequently. The C2C12 cells were treated respectively with serum-free medium containing $1 \mu \mathrm{M}$ TAT-CAIII or $1 \mu \mathrm{M}$ CAlll for $1 \mathrm{~h}$ and the intracellular distributions of fusion proteins were observed by indirect immunofluorescence. The effect of TAT-CAIII on C2C12 cell apoptosis induced by hypoxia/reoxygenation was detected by flow cytometry.

Results: The CAIII and TAT-CAIII fusion proteins were expressed and purified successfully. After being cultured for $1 \mathrm{~h}$, green fluorescence was visible in TATCAIII group cells under the fluorescence microscope, while no fluorescence was found in the CAIII group. Compared with the oxygen-glucose deprivation group, the apoptosis rate of $\mathrm{C} 2 \mathrm{C} 12$ cells induced by hypoxia/reoxygenation in the TAT-CAIII group decreased significantly $(p<0.001)$.

Conclusions: The purified TAT-CAlll could be transferred into cells efficiently and clearly decreased the apoptosis rate of C2C12 cells induced by hypoxia/reoxygenation, which indicated that it had antioxidative activity. This study lays an experimental basis for future research on the relationship between CAIII and muscle fatigue.
\end{abstract}

Key words: carbonic anhydrase III, expression, purification, protein transduction domain, hypoxia/reoxygenation, apoptosis.

\section{Introduction}

Carbonic anhydrases (CAs) are zinc metalloenzymes that catalyze the reversible hydration of $\mathrm{CO}_{2}$ to bicarbonate. At least 16 carbonic anhydrase isoforms have been described so far in mammals [1]. They play very important roles in many physiological processes, including respiration, gluconeogenesis, signal transduction, and formation of gastric acid [2]. Carbonic 
anhydrase III (CAIII) is one specific member of this family which is remarkably abundant in slow skeletal muscles (10\% of the cytosolic protein content), adipocytes (24\% of the soluble protein), and liver ( $8 \%$ of the soluble protein) [1]. Despite the notable abundance of CAIII in skeletal muscles, its physiological role remains a mystery [3].

As we know, the increase of hydrogen ions, reactive oxygen species (ROS) and the decrease of ATP have been considered important causes of muscle fatigue [4-6]. Interestingly, CAlll has hydrase activity which plays important roles in regulating intracellular pH and maintaining the appropriate acidbase balance in organisms [7]. Furthermore, CAlll has antioxidative activity which can protect cells from oxidative damage $[3,8]$. Finally, CAIII may also involve oxidative phosphorylation and energy metabolism. For example, the lack of CAlll attenuated the synthesis of ATP by mitochondria [9]. Because CAlll has multiple biological activities which can dissipate or resist some fatigue-related substances, we consider that the changes of protein levels and activities of CAlll in skeletal muscles might be related to the occurrence of muscle fatigue [10]. Hence, we hypothesize that CAIII supplementation may contribute to dissipation of fatigue.

Currently, the greatest barrier is that macromolecules (such as CAlll, $29 \mathrm{kDa}$ ) could not penetrate across the plasma membrane; only small molecules (less than $600 \mathrm{Da}$ ) can do so. TAT is one small region of protein and it has been shown that various TAT fusion proteins up to $120 \mathrm{kDa}$ can be efficiently transduced into multiple mammalian cells and tissues [11-13]. In view of this, this study was designed to express, purify and verify CAIII and TAT-fused CAIII (TAT-CAIII) proteins. Furthermore, the transmembrane abilities of them were examined by indirect immunofluorescence. Finally, the effect of TAT-CAlll on C2C12 cell apoptosis induced by H/R was detected by flow cytometry.

The purpose of this study was to observe whether TAT-CAll could transfer into cells and retain its biological activities. This work lays a basis for a further study to determine whether supply of TAT-CAIII could dissipate fatigue.

\section{Material and methods}

\section{Bacterial strains, plasmids and enzymes}

Escherichia coli DH5a (Novagen, Germany) was used for transformation of synthesized DNA and E. coli BL21 (DE3) (Novagen, Germany) was used as a host strain for expression. The plasmid pET28a (Novagen, Germany) was used for expression of the synthesized gene in E. coli. The BamH 1 and Hind 1 restriction enzymes and T4 DNA ligase were purchased from Fermentas (Lithuania).

\section{Cell culture}

Mouse C2C12 myoblast cells were obtained from the Shanghai Cellular Institute of China Scientific Academy. Cells were cultured in Dulbecco's Modified Eagle Medium (DMEM, Gibco, USA) supplemented with $10 \%$ fetal bovine serum (FBS, Gibco, USA) and penicillin $(100 \mathrm{U} / \mathrm{ml})$, streptomycin $(100 \mu \mathrm{g} / \mathrm{ml})$ and glutamine $(2 \mathrm{mM})$ in $5 \% \mathrm{CO}_{2}$ at $37^{\circ} \mathrm{C}$.

\section{Construction of CAIII and TAT-CAlll gene}

The gene sequence of CAlll was found in the GenBank database (GenBank accession no. M22413). The sequence encoding the 11 amino acids TAT-PTD (YGRKKRRQRRR) was found in the GenBank database (GenBank accession no. DQ979025). The CAlll gene and TAT-CAlll fusion gene were designed with BamH I and Hind III site. The CAIII gene was amplified with 35 PCR cycles by using the following primers: primer 1 (5'AGAGGATCCGAATTCGCTAAGGAGTGGGGTTAC3'), primer 2 (5'AGAAAGCTTCTTGAAGGAGGCCCTCACCAC3'). The TAT-CAIII gene was amplified with 35 PCR cycles by using the following primers: primer 1 (5'AGAGGATCCG AATTCTATGGCAGGAAGAAGCGG3'), primer 2 (5'AGAAAGCTTCTTGAAGGAGGCCCTCAC(AC3'). All primers were synthesized by Invitrogen Biotechnology (Shanghai, China).

\section{Construction of Escherichia coli expression strains}

The plasmid pET28a and the amplified DNA were digested with BamH I and Hind III, and then were ligated with T4 DNA ligase and transformed into E. coli $\mathrm{DH} 5 \mathrm{a}$. The positive recombinant plasmids pET28a-CAIII and pET28a-TAT-CAIII were confirmed by restriction enzyme digestion and DNA sequencing (Invitrogen Biotechnology, Shanghai, China). The recombinant plasmids confirmed were then transformed into E. coli BL21 (DE3) for protein expression.

\section{Expression of fusion proteins}

The transformants were grown in LB medium (1.0\% tryptone, $1.0 \% \mathrm{NaCl}, 0.5 \%$ yeast extract, $\mathrm{pH}$ 7.0) containing $50 \mathrm{mg} / \mathrm{l}$ kanamycin at $37^{\circ} \mathrm{C}$. When OD600 reached 0.9 , IPTG was added to the final concentration of $1.0 \mathrm{mM}$. After incubation at $37^{\circ} \mathrm{C}$ for $8 \mathrm{~h}$, the bacteria were collected, lysed, and then boiled in SDS-PAGE loading buffer. The expression patterns were analyzed by $12 \%$ SDS-PAGE.

\section{Purification of fusion proteins under denaturing conditions}

After induction at $37^{\circ} \mathrm{C}$ for $8 \mathrm{~h}$, the bacteria were collected and resuspended in buffer $\mathrm{A}(50 \mathrm{mM}$ $\mathrm{NaH}_{2} \mathrm{PO}_{4}, 10 \mathrm{mM}$ imidazole, $500 \mathrm{mM} \mathrm{NaCl}, 10 \%$ glycerol, $1 \mathrm{mM}$ PMSF, pH 8.0), and then disrupted 
by sonication (Ultrasonic Cell Crusher JY92-2D, Ningbo Scientz Biotechnology, China) at $300 \mathrm{~W}$ for 100 cycles (4 s working, $4 \mathrm{~s}$ free) on ice. The fusion proteins were present in the form of inclusion bodies. The supernatant was removed by centrifugation at 15,000 rpm for $20 \mathrm{~min}$ at $4^{\circ} \mathrm{C}$ and the precipitation was resuspended in buffer $\mathrm{B}(10 \mathrm{mM}$ Tris- $\mathrm{HCl}, 100 \mathrm{mM} \mathrm{NaH}{ }_{2} \mathrm{PO}_{4}, 8 \mathrm{M}$ urea, $\mathrm{pH}$ 8.0). After being centrifuged at $15,000 \mathrm{rpm}$ for $20 \mathrm{~min}$ at $4^{\circ} \mathrm{C}$, the supernatant was loaded onto a Ni-NTA affinity chromatography column (Novagen, Germany). Then, the column was washed with buffer $\mathrm{B}$ and buffer $\mathrm{C}\left(10 \mathrm{mM}\right.$ Tris- $\mathrm{HCl}, 100 \mathrm{mM} \mathrm{NaH}_{2} \mathrm{PO}_{4}, 8 \mathrm{M}$ urea, $\mathrm{pH}$ 6.9) to remove the unbound proteins and eluted with buffer D (10 mM Tris- $\mathrm{HCl}, 100 \mathrm{mM} \mathrm{NaH}_{2} \mathrm{PO}_{4}$, $8 \mathrm{M}$ urea, $\mathrm{pH}$ 4.5). Eluates were collected and analyzed by $12 \%$ SDS-PAGE. The densitometry of the fusion proteins was performed with the FR-980 BioElectrophoresis Image Analysis System (Furi, Shanghai, China) and the software SmartView plus (Furi, Shanghai, China).

The fusion proteins supplemented with $1 \%$ CHAPS (Sigma) and 10\% glycerol were renatured by urea gradient dialysis. In short, the protein buffer was put into a bag filter and then submerged in $4 \mathrm{M}$ urea buffer (10 mM Tris- $\mathrm{HCl}, 100 \mathrm{mM} \mathrm{NaH}_{2} \mathrm{PO}_{4}$, $4 \mathrm{M}$ urea, $\mathrm{pH}$ 4.5), $2 \mathrm{M}$ urea buffer (10 mM Tris- $\mathrm{HCl}$, $100 \mathrm{mM} \mathrm{NaH}{ }_{2} \mathrm{PO}_{4}, 2 \mathrm{M}$ urea, $\mathrm{pH}$ 4.5), $1 \mathrm{M}$ urea buffer $\left(10 \mathrm{mM}\right.$ Tris- $\mathrm{HCl}, 100 \mathrm{mM} \mathrm{NaH}_{2} \mathrm{PO}_{4}, 1 \mathrm{M}$ urea, $\mathrm{pH} 4.5$ ) in turn for gradient dialysis (3 times per concentration, $6 \mathrm{~h} /$ time). Then the protein buffer was dialyzed against 0.01M PBS (pH 7.4) 3 times (4 h/time). The whole dialysis procedure was performed at $4^{\circ} \mathrm{C}$ with magnetic stirring. Finally, the fusion proteins were analyzed by $12 \%$ SDS-PAGE and their concentrations were determined by BCA protein assay, using bovine serum albumin as the standard.

\section{Purification of TAT-CAlll under native conditions}

After induction with $1.0 \mathrm{mM} \mathrm{IPTG}$ at $25^{\circ} \mathrm{C}$ for $24 \mathrm{~h}$, the pET28a-TAT-CAlll transformed bacteria were collected and resuspended in $10 \mathrm{ml} \mathrm{Ni}$-buffer0 (50 mM NaH $2 \mathrm{PO}_{4}, 300 \mathrm{mM} \mathrm{NaCl}, \mathrm{pH} \mathrm{8.0)}$ at $4^{\circ} \mathrm{C}$ for $30 \mathrm{~min}$, and then disrupted by sonication as above. TAT-CAIII was partly present in a dissoluble form. The supernatant was collected by centrifugation at $12,000 \mathrm{rpm}$ for $20 \mathrm{~min}$ at $4^{\circ} \mathrm{C}$ and then supplemented with $20 \mathrm{mM}$ imidazole. After the $\mathrm{Ni}$ NTA affinity chromatography column was washed with $20 \mathrm{ml} \mathrm{Ni}$-buffer-0, the supernatant was loaded onto the column and released slowly $(15 \mathrm{ml} / \mathrm{h})$. Then the column was washed with $10 \mathrm{ml} \mathrm{Ni}$-buffer20 (50 mM NaH${ }_{2} \mathrm{PO}_{4}, 20 \mathrm{mM}$ imidazole, $300 \mathrm{mM}$ $\mathrm{NaCl}, \mathrm{pH}$ 8.0), Ni-buffer-50 (50 mM NaH${ }_{2} \mathrm{PO}_{4}$, $50 \mathrm{mM}$ imidazole, $300 \mathrm{mM} \mathrm{NaCl}$, pH 8.0), Ni-buffer100 (50 mM NaH ${ }_{2} \mathrm{PO}_{4}, 100$ mM imidazole, 300 mM
$\mathrm{NaCl}, \mathrm{pH}$ 8.0), and Ni-buffer-250 (50 mM NaH $\mathrm{PO}_{4}$, $250 \mathrm{mM}$ imidazole, $300 \mathrm{mM} \mathrm{NaCl}, \mathrm{pH}$ 8.0) in turn. All of the eluates were collected and analyzed by $12 \%$ SDS-PAGE. According to the result, the eluate washed by Ni-buffer-250 was dialyzed against $0.01 \mathrm{M} \mathrm{PBS}\left(\mathrm{pH} \mathrm{7.4)}\right.$ at $25^{\circ} \mathrm{C} 3$ times ( $8 \mathrm{~h} /$ time). The protein concentration was determined by BCA protein assay.

\section{Western blot identification}

The fusion proteins purified were electrotransferred onto two pieces of nitrocellulose membranes. After being stained with Ponceau, the membranes were decolored with transmembrane buffer and then blocked with 5\% non-fat milk in 0.05\% Tween/PBS (PBST) for $2 \mathrm{~h}$. Then the membranes were washed 3 times with PBST for 10 min. One piece of membrane was incubated subsequently with mouse anti-His-tag monoclonal antibody (Tiangen, China, 1 : 1000 diluted in PBS supplemented with $5 \%$ non-fat milk) for $3 \mathrm{~h}$, and the other was incubated with rabbit anti-rat-CAlll polyclonal antibody (provided by the Institute of Neurology, Fudan University, 1 : 1600 diluted in PBS supplemented with $5 \%$ non-fat milk) for $3 \mathrm{~h}$, followed by being washed as described above. The former was incubated further with HRP-conjugated goat anti-mouse IgG (Santa Cruz, USA, 1 : 1000 diluted in PBS supplemented with $5 \%$ non-fat milk) as the second antibody for $1 \mathrm{~h}$. The latter was incubated with HRPconjugated goat anti-rabbit IgG (Sigma, USA, $1: 2000$ diluted in PBS supplemented with $5 \%$ nonfat milk) as the second antibody for $1 \mathrm{~h}$, washed with the same procedure as above and then revealed with DAB substrate (Sigma).

\section{Phosphatase activity assay}

The fusion proteins identified were electrotransferred onto one piece of nitrocellulose membrane. The membrane was immersed into buffer $A B S$ (20 mM NaAc, $0.8 \% \mathrm{NaCl}, 0.02 \% \mathrm{KCl}, \mathrm{pH} 5.5$ ) on a shaking table for $20 \mathrm{~min}$, then blocked with $5 \%$ polyvinylpyrrolidone (PVP) in buffer ABS and stored at $4^{\circ} \mathrm{C}$ overnight. After being washed with buffer ABS for $5 \mathrm{~min}$, the membrane was incubated with phosphatase reaction solution (50 mM NaAc, $20 \mathrm{mM}$ $\mathrm{MgCl}_{2}$, $5 \mathrm{mM}$ nitrophenyl phosphate, $2 \mathrm{mM}$ fast garnet $\mathrm{GBC}, \mathrm{pH} \mathrm{5.5)}$ at $37^{\circ} \mathrm{C}$ for $45 \mathrm{~min}$. Then the membrane was washed 3 times with buffer ABS for $5 \mathrm{~min}$. The phosphatase activity staining of fusion proteins was viewed and photographed using a Nikon camera (Coolpix, P80, Japan).

\section{Detection of the TAT-CAll transmembrane ability}

The C2C12 cells were inoculated in a 24-well plate at a density of $1 \times 10^{6}$ cells/well. After $24 \mathrm{~h}$, 
the cells were treated respectively with serum-free medium containing $1 \mu \mathrm{M}$ TAT-CAIII and $1 \mu \mathrm{M}$ CAIII for $1 \mathrm{~h}$, and the negative control group cells were cultured with serum-free medium only. The cells were washed 3 times with PBS for 10 min to remove the fusion proteins outside the cells. Then the cells were fixed with $4 \%$ paraformaldehyde for 30 min, followed by being washed 3 times with PBS for $5 \mathrm{~min}$. After being blocked with $5 \%$ FBS in $0.3 \%$ Triton X-100/PBS for $30 \mathrm{~min}$, the cells were incubated with mouse anti-His-tag monoclonal antibody (1: 500 diluted in PBS supplemented with $5 \%$ FBS and $0.1 \%$ Triton $\mathrm{X}-100$ ) at $37^{\circ} \mathrm{C}$ for $1 \mathrm{~h}$. The cells were washed 3 times with PBS for 5 min and incubated further with FITC-conjugated goat anti-mouse IgG (Santa Cruz, USA, 1:500 diluted in PBS) as the second antibody at $37^{\circ} \mathrm{C}$ for $45 \mathrm{~min}$, washed with the same procedure as above and then observed using an inverted fluorescence microscope (Nikon, Japan).

\section{Effect of TAT-CAlll on C2C12 cell apoptosis induced by $H / R$}

The C2C12 cells were inoculated in 24-well plates at a density of $1 \times 10^{6}$ cells/well. After $24 \mathrm{~h}$, the cells were treated respectively with serum-free medium containing $0.5,1,2 \mu \mathrm{M}$ TAT-CAIII and $1 \mu \mathrm{M}$ CAIII for $1 \mathrm{~h}$. The oxygen-glucose deprivation (OGD) group and the normal group cells were cultured with serum-free medium containing the same volume of PBS. For H/R treatment, the culture media were replaced with a deoxygenated glucose-free or an oxygenated glucose-containing (the normal group) DMEM at $\mathrm{pH}$ 7.4. The cells were then transferred into a hypoxic chamber containing a mixture of $5 \%$ $\mathrm{CO}_{2}, 10 \% \mathrm{H}_{2}$ and $85 \% \mathrm{~N}_{2}$ at $37^{\circ} \mathrm{C}$ or normal culture conditions for $3 \mathrm{~h}$. The deoxygenated glucose-free DMEM was then replaced by common culture medium and returned to normal culture conditions for 4 h. C2C12 cell apoptosis was detected by flow cytometry. The cells were detached with $0.25 \%$ trypsin and resuspended in PBS. FITC-Annexin $\mathrm{V}$ and PI were added to $10^{5}$ cells, after which the cells were placed in the dark at room temperature for 15 min according to the manufacturer's instructions (Apoptosis Detection Kit, BD Biosciences). Flow cytometry was then performed using a FACSCantoTM Flow Cytometer (BD Biosciences). Early apoptotic cells stained with FITC-Annexin $\mathrm{V}$ alone, whereas late apoptotic cells and necrotic cells stained with both FITC-Annexin V and PI.

\section{Statistical analysis}

Data are expressed as the mean \pm SE. Statistical analyses were performed with STATA 7.0 software. The statistical significance of the results was assessed either by Student's $t$-test when compar- ing two groups or, as indicated, by one-way analysis of variance (ANOVA) followed by Tukey post-hoc test for multiple group comparison. Value of $p<0.05$ was considered to be statistically significant.

\section{Results}

\section{Construction of CAIII and TAT-CAlll expression plasmids}

The recombinant plasmids pET28a-CAIII and PET28a-TAT-CAIII were confirmed by restriction enzyme digestion and DNA sequencing. The agarose gel electrophoresis showed that the sizes of digested products were in good agreement with the nucleotide lengths of CAIII, TAT-CAIII and pET28a. Furthermore, the sequencing results showed that the nucleotide sequences of CAIII and TAT-CAllI were consistent with the GenBank report, which indicated that the CAIII and TAT-CAIII plasmid expression vectors were constructed successfully.

\section{Expression and purification of fusion proteins}

The recombinant plasmids confirmed were transformed into E. coli BL21 (DE3) for protein expression. After being induced by IPTG, both of the fusion proteins' expression amounts were about $10 \%$ of the total protein. The fusion proteins were purified under denaturing conditions, and then analyzed by $12 \%$ SDS-PAGE. The results showed that their relative molecular masses were basically identical with the calculated molecular weights according to the deduced amino acid sequences and their purities were both higher than $80 \%$. The concentrations of TAT-CAIII and CAIII determined by BCA protein assay were $0.25 \mathrm{mg} / \mathrm{ml}$ and $0.38 \mathrm{mg} / \mathrm{ml}$ respectively.

The renaturation efficiency was very low and the final concentration of TAT-CAIII obtained was only $0.25 \mathrm{mg} / \mathrm{ml}$. Therefore, the re-induction of pET28aTAT-CAIII transformed bacteria was carried out, and finally the soluble TAT-CAIII was obtained after induction culture overnight at $25^{\circ} \mathrm{C}$ (Figure $1 \mathrm{~A}$ ). Then we purified it under native conditions and found that the TAT-CAIII was dissolved mostly in Nibuffer-250 buffer (Figure $1 \mathrm{~B}$ ) and its purity was over $90 \%$ (Figure $1 \mathrm{C}$ ). The concentration of TAT-CAIII obtained reached $0.5 \mathrm{mg} / \mathrm{ml}$, which represented an increase of $100 \%$ compared with the concentration under denaturing conditions.

\section{Identification of the purified fusion proteins}

The fusion proteins purified were verified by Ponceau staining, western blot and phosphatase activity staining subsequently. The Ponceau staining showed single clear bands of the predicted sizes of TAT-CAIII and CAIII (Figure $2 \mathrm{~A}-\mathrm{a}$ ). From the immunoblotting results, we could see that both of them could react immunologically with anti-CAIII 
polyclonal antibody and anti-His-tag monoclonal antibody (Figure $2 \mathrm{~A}-\mathrm{b}, \mathrm{c}$ ). The phosphatase activity staining revealed that both of them had intrinsic phosphatase activity and the background of the staining was clean (Figure $2 \mathrm{~A}-\mathrm{d}$ ).

\section{Detection of the TAT-CAlll transmembrane ability}

The transmembrane ability of TAT-CAIII into C2C12 cells was confirmed by indirect immunofluorescence. The results showed that there were visible green fluorescence signals in the cells treated with serum-free medium containing TAT-CAIII, whereas fluorescence signals were absent in the cells treated with CAIII and the negative control group (Figure 2B).

\section{Effect of TAT-CAIII on C2C12 cell apoptosis induced by $\mathrm{H} / \mathrm{R}$}

Examples of flow cytometric assays from control and experimental treatment groups are depicted in Figure 3 and Table I. Compared with the OGD group, the apoptosis rate of $\mathrm{C} 2 \mathrm{C} 12$ cells induced by H/R in the CAIII group decreased slightly $(p>0.05)$, while the apoptosis rate of $\mathrm{C} 2 \mathrm{C} 12$ cells in the TAT-CAIII group decreased very significantly $(p<0.001)$ and there were significant differences between the CAIII group and TAT-CAIII group too $(p<0.01)$. Further study revealed that the apoptosis rate of $\mathrm{C} 2 \mathrm{C} 12$ cells in the TAT-CAIII group decreased clearly with the increase of incubating concentration and there were significant differences in the $1.0 \mu \mathrm{M}$ TAT-CAIII group and $2.0 \mu \mathrm{M}$ TAT-CAll group compared with the $0.5 \mu \mathrm{M}$ TAT-CAIII group $(p<0.05)$.

\section{Discussion}

CAll is present in high concentrations ( $2 \%$ of wet weight) in the cytoplasm of slow twitch fibers such as soleus muscle, but is largely absent from white muscles such as the anterior tibialis, extensor digitorum longus and the pectoral muscle [3]. Why such large amounts of CAlll have come to play a physiological role in skeletal muscles remains a mystery. Recently, it has been suggested that CAll might have the function of anti-muscle fatigue. For instance, Cote et al. [14] found that inhibiting the CAlll activity of type I muscle can influence fatigability. After 55 days of horizontal bed rest with resistive vibration exercise countermeasures, Moriggi et al. [15] found that the protein level of CAIII in the soleus was evidently increased. Another study showed that the mRNA concentrations of CAIII in the vastus lateralis muscle in hypoxia-trained subjects were significantly increased by $74 \%$ compared to those of normoxia-trained subjects [16]. Furthermore, CAIII has multiple biological activities which can dissipate fatigue-related substances

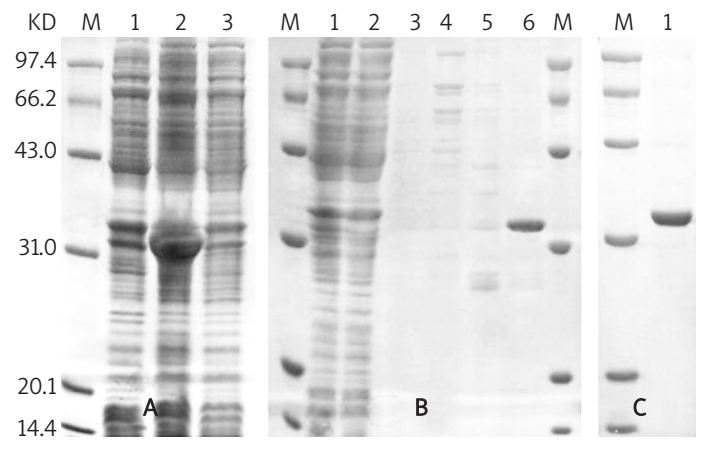

Figure 1. Purification of TAT-CAlll under native conditions. $M$ - Pre-stained protein molecular weight marker. A - Protein expression of pET28a-TAT-CAIII transformed bacteria ( 1 - total proteins before being induced by IPTG; 2 - total proteins after being induced by IPTG; 3 - proteins in the supernatants after being induced by IPTG). B - Purification of the TAT-CAlll fusion protein (1 - cell supernatants; 2 flow-through; 3 - Ni-buffer-20 wash; 4 - Ni-buffer50 wash; 5 - Ni-buffer-100 wash; 6 - Ni-buffer-250 elution). C - (1 - Purified TAT-CAIII)

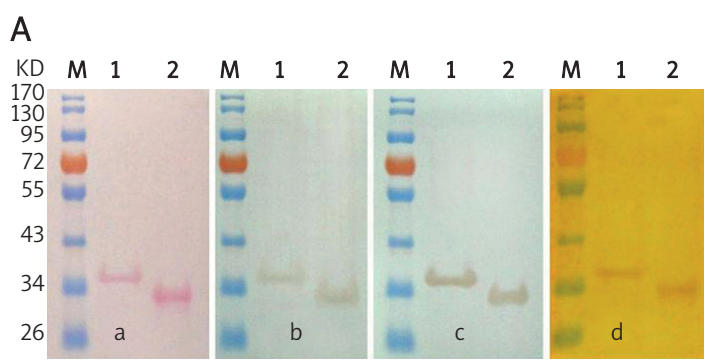

B

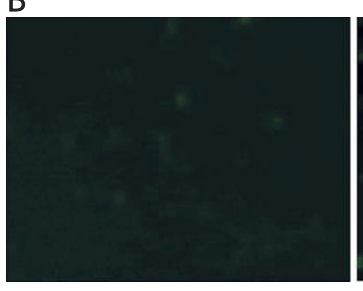

Cells incubated in DMEM with CAIII

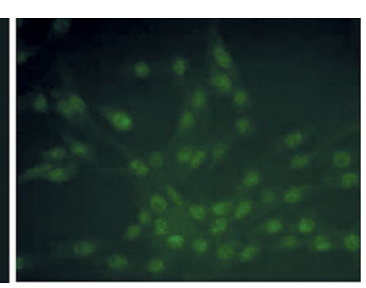

Cells incubated in DMEM with TAT-CAIII
Figure 2. Identification of the purified products and determination of the TAT-CAll transmembrane ability. A - Ponceau staining, western blot identification and phosphatase activity staining of the purified products ( $a$ - Ponceau staining; $b$ - Reacting with the anti-CAlll polyclonal antibody; $c$ - Reacting with the anti-His-tag monoclonal antibody; $d$ - Phosphatase activity staining). $M$ - Pre-stained protein molecular weight marker; 1 - Purified TAT-CAlll; 2 Purified CAIII. B - Identification of the TAT-CAIII transmembrane ability (200x)

[7-9], so we hypothesize that CAlll supplementation may contribute to dissipation of fatigue [10].

Currently, the greatest barrier is that CAll could not penetrate across the plasma membrane, which only allows small molecules (less than $600 \mathrm{Da}$ ) to be delivered into cells efficiently. Protein transduc- 
A

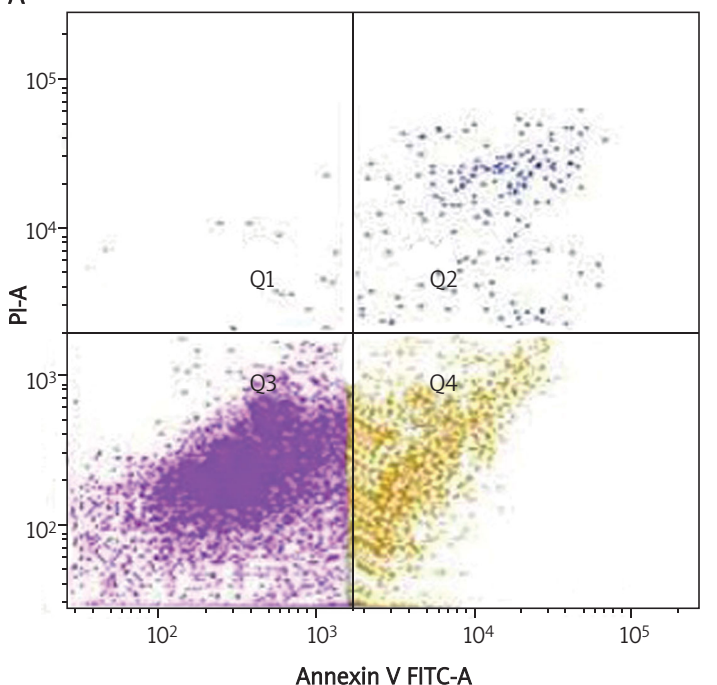

C

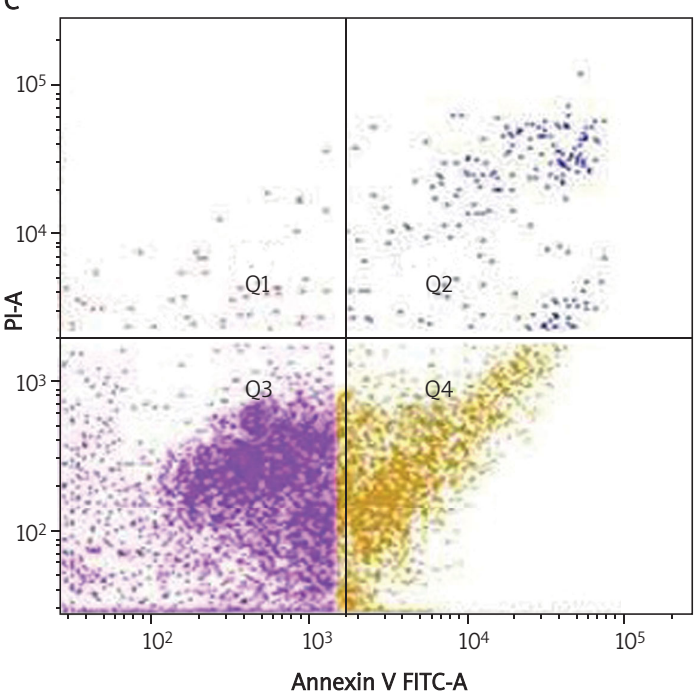

E

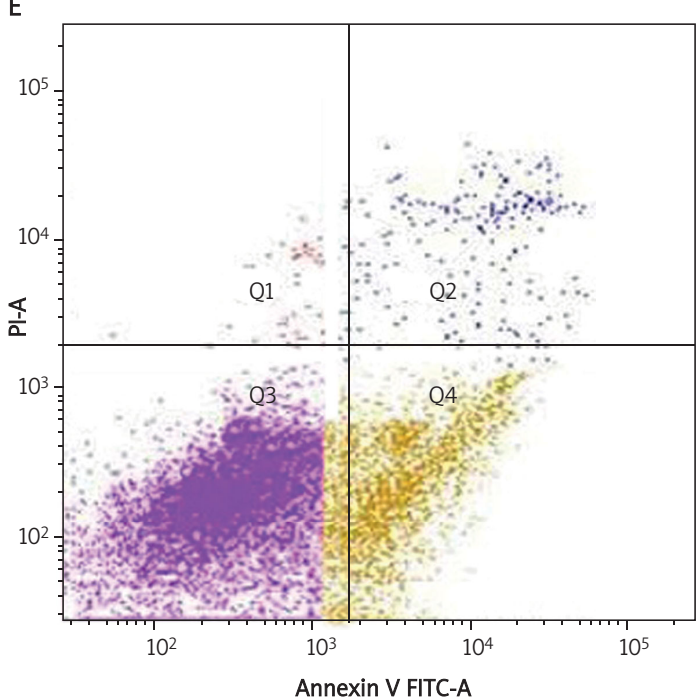

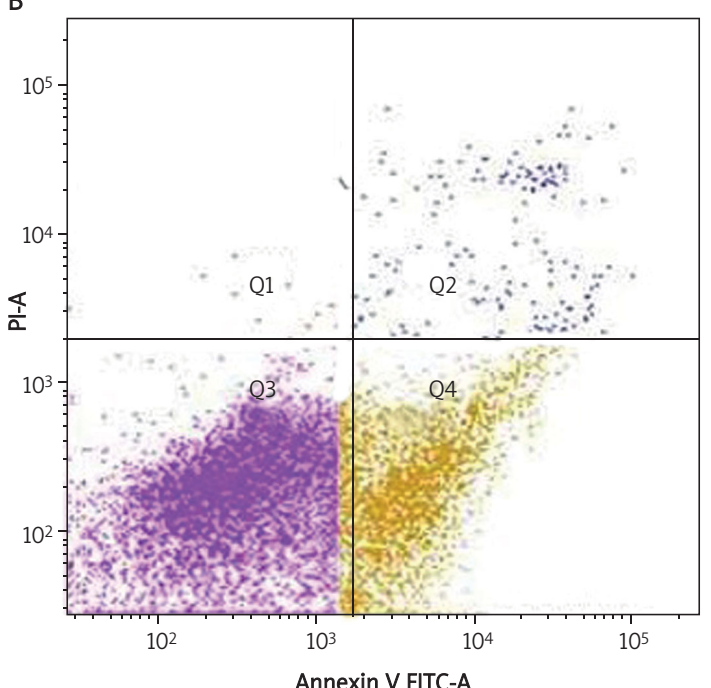

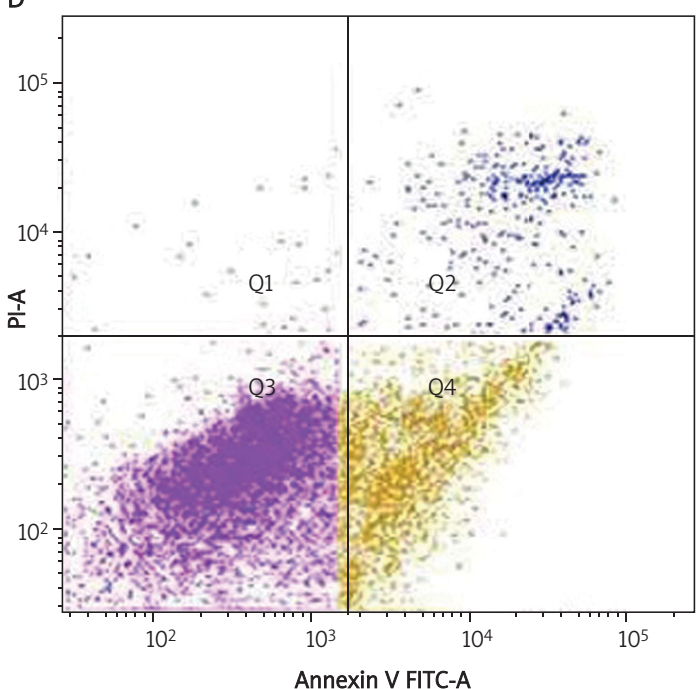

F

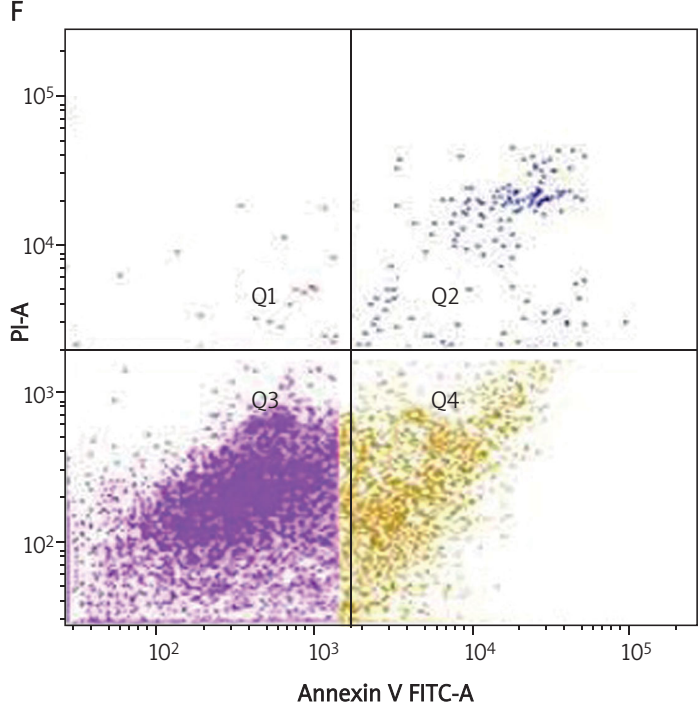

Figure 3. Flow cytometric assay showing C2C12 cell apoptosis induced by H/R. A - Normal group; B - OGD group; C - CAIII group; D - $0.5 \mu \mathrm{M}$ TAT-CAIII group; $\mathrm{E}-1.0 \mu \mathrm{M}$ TAT-CAIII group; $\mathrm{F}-2.0 \mu \mathrm{M}$ TAT-CAIII group (Q1, Q2, Q3 and Q4: necrotic, late apoptotic, viable and early apoptotic cells) 
tion technology is a newly developed method which allows multiple proteins, peptides and biologically active compounds to penetrate into cells and tissues by protein transduction domains (PTDs) [17]. In recent years, it has been found that several small regions of proteins called PTDs can deliver multiple proteins into living cells rapidly and efficiently. These include carrier peptides derived from HIV-1 TAT protein, Drosophila Antennapedia (Antp) protein and herpes simplex virus VP22 protein, etc [13]. TAT-PTD is one member of this PTD family and it is composed of 11 amino acids (YGRKKRRQRRR). Indeed, it has been shown that various TAT fusion proteins can be efficiently transduced into multiple mammalian cells and tissues [11-13]. In this study, the TAT-CAIII fusion gene was constructed by ligating the TAT-PTD gene to the CAlll gene. Then we constructed the recombinant plasmids and transformed them into E. coli BL21 (DE3) for protein expression.

After being induced by IPTG at $37^{\circ} \mathrm{C}$, the fusion proteins were present in the form of inclusion bodies. Therefore, the fusion proteins were purified under denaturing conditions and then renatured by urea gradient dialysis. However, the proteins were more prone to precipitate and the final concentration of TAT-CAlll obtained was only $0.25 \mathrm{mg} / \mathrm{ml}$. Therefore, the re-induction of pET28a-TAT-CAlll transformed bacteria was carried out, and finally the soluble TAT-CAlll was obtained after induction culture overnight at $25^{\circ} \mathrm{C}$. Then we purified the TAT-CAIII fusion protein under native conditions and the concentration of TAT-CAlll obtained reached $0.5 \mathrm{mg} / \mathrm{ml}$. This indicated that we could avoid protein precipitation in the renaturation process by changing induction modes to produce soluble proteins. Finally, western blot results showed that the fusion proteins were obtained successfully.

As we know, CAlll has multiple biological activities including esterase, phosphatase, and $\mathrm{CO}_{2}$ hydration activities [18]. Considering that its $\mathrm{CO}_{2}$ hydration activity is very low, we detected the phosphatase activity of the fusion proteins to investigate whether they still have biological activities. In this study, enzyme staining was performed on the nitrocellulose membrane, which solved the deficiency of enzyme and substrate reaction insufficiency and avoided the influence of SDS when stained on the gel. Furthermore, we used 5\% polyvinylpyrrolidone as the blocking buffer instead of bovine serum albumin (BSA) or FBS or non-fat milk, which avoided the influences of other miscellaneous proteins among them. The results showed that both of them still had intrinsic phosphatase activity and the background of the staining was clean. The indirect immunofluorescence results showed that there were visible green fluorescence signals in the cells treated with serum-
Table I. Effect of TAT-CAIII on C2C12 cell apoptosis induced by $\mathrm{H} / \mathrm{R}$

\begin{tabular}{|c|c|}
\hline Group & Apoptosis rate [\%] \\
\hline Normal & $17.27 \pm 2.46$ \\
\hline OGD & $34.47 \pm 1.0^{\star * *}$ \\
\hline CAIII & $32.5 \pm 1.37^{\star * \star}$ \\
\hline TAT-CAIII $0.5 \mu \mathrm{M}$ & $26.4 \pm 1.08^{* * \Delta} \boldsymbol{\nabla}$ \\
\hline $1.0 \mu \mathrm{M}$ & $23.4 \pm 1.23^{\star \Delta} \Delta \star \boldsymbol{\nabla}^{\star}$ \\
\hline $2.0 \mu \mathrm{M}$ & $22.47 \pm 1.5^{\star \Delta} \Delta \star$ \\
\hline
\end{tabular}

Significant differences compared to normal group, ${ }^{*} p<0.05$, ${ }^{* *} p<0.01$, ${ }^{* * *} p<0.001$. Significant differences compared to OGD group, $\Delta p<0.001$. Significant differences compared to CAlll group, $\mathbf{\nabla} p<0.01$. Significant differences compared to $0.5 \mu$ M TAT-CAlll group, ${ }^{\star} p<0.05$

free medium containing TAT-CAIII, which demonstrated that TAT could mediate CAIII transfer into C2C12 cells efficiently.

Reactive oxide species act as signaling molecules in various cell types, participating in or modifying physiological events related to receptor-ligand binding and transcriptional activation [19]. Reactive oxide species can affect signal transduction in post-hypoxic cells, and ROS are able to initiate cell death programs in the form of apoptosis or necrosis [19]. Otherwise, the increased production of ROS can result in muscle fatigue and/or injury [5]. Interestingly, CAlll has antioxidative activity which can protect cells from oxidative damage [3, 8]. In agreement with the literature reports, we also found that TAT-CAIII could clearly decrease the apoptosis rate of $\mathrm{C} 2 \mathrm{C} 12$ cells induced by $\mathrm{H} / \mathrm{R}$, which indicated that it still had antioxidative activity. Further study revealed that TAT-CAIII decreased apoptosis of $\mathrm{C} 2 \mathrm{C} 12$ cells in a concentration-dependent manner. However, CAlll had no obvious protective effect on the cell injury induced by $H / R$, probably because it could not be transferred into cells. The study lays a basis for our further study to determine whether supply of TAT-CAlll could dissipate fatigue.

In conclusion, we successfully constructed the CAIII and TAT-CAIII plasmid expression vectors and purified the fusion proteins efficiently. The phosphatase activity staining results showed that both CAIII and TAT-CAIII had intrinsic phosphatase activity. The purified TAT-CAlll could be efficiently transduced into $\mathrm{C} 2 \mathrm{C} 12$ cells and it could clearly decrease the apoptosis rate of $\mathrm{C} 2 \mathrm{C} 12$ cells induced by H/R, which indicated that it had antioxidative activity. However, there are still many problems to be solved. One major disadvantage of protein transduction technology is the lack of target specificity. Therefore, for protein therapy, it is very important to determine whether TAT-CAIII has adverse effects on healthy tissues. Despite this, we prefer protein transduction technology to gene therapy because it can directly control the intracellular protein levels. 


\section{Acknowledgments}

These first two authors contributed equally to this work. This research was supported by the National Natural Science Foundation of China (No. 30771044) and youth fund of Fudan University (09FQ66).

\section{References}

1. Vullo D, Nishimori I, Scozzafava A, Supuran CT. Carbonic anhydrase activators: Activation of the human cytosolic isozyme III and membrane-associated isoform IV with amino acids and amines. Bioorg Med Chem Lett 2008; 18: 4303-7.

2. Kim G, Lee TH, Wetzel P, et al. Carbonic anhydrase III is not required in the mouse for normal growth, development, and life span. Mol Cell Biol 2004; 24: 9942-47.

3. Zimmerman UJ, Wang P, Zhang X, Bogdanovich $S$, Forster R. Anti-oxidative response of carbonic anhydrase III in skeletal muscle. IUBMB Life 2004; 56: 343-7.

4. Lindinger MI, Kowalchuk JM, Heigenhauser GJ. Applying physicochemical principles to skeletal muscle acid-base status. Am J Physiol Regul Integr Comp Physiol 2005; 289: R891-4.

5. Reid MB. Free radicals and muscle fatigue: Of ROS, canaries, and the IOC. Free Radic Biol Med 2008; 44: 169-79.

6. De Haan A, Koudijs JC. A linear relationship between ATP degradation and fatigue during high-intensity dynamic exercise in rat skeletal muscle. Exp Physiol 1994; 79: 865-8.

7. Henry RP. Multiple roles of carbonic anhydrase in cellular transport and metabolism. Annu Rev Physiol 1996; 58: 523-38.

8. Roy P, Reavey E, Rayne M, et al. Enhanced sensitivity to hydrogen peroxide-induced apoptosis in Evi1 transformed Rat1 fibroblasts due to repression of carbonic anhydrase III. FEBS J 2010; 277: 441-52.

9. Liu M, Walter GA, Pathare NC, Forster RE, Vandenborne K. A quantitative study of bioenergetics in skeletal muscle lacking carbonic anhydrase III using 31P magnetic resonance spectroscopy. Proc Natl Acad Sci USA 2007; 104: 371-6.

10. Shang XL, Chen SY, Ren HM, Li YX, Huang H. Carbonic Anhydrase III: the new hope for the elimination of exercise-induced muscle fatigue. Med Hypotheses 2009; 72: 427-9.

11. Jeong MS, Kim DW, Lee MJ, et al. HIV-1 Tat-mediated protein transduction of human brain creatine kinase into PC12 cells. BMB Rep 2008; 41: 537-41.

12. Kubo E, Singh DP, Fatma N, Akagi Y. TAT-mediated peroxiredoxin 5 and 6 protein transduction protects against high-glucose-induced cytotoxicity in retinal pericytes. Life Sci 2009; 84: 857-64.

13. Wagstaff KM, Jans DA. Protein transduction: cell penetrating peptides and their therapeutic applications. Curr Med Chem 2006; 13: 1371-87.

14. Côté $C$, Riverin H, Barras MJ, Tremblay RR, Frémont $P$, Frenette J. Effect of carbonic anhydrase III inhibition on substrate utilization and fatigue in rat soleus. Can J Physiol Pharmacol 1993; 71: 277-83.

15. Moriggi M, Vasso M, Fania C, et al. Long term bed rest with and without vibration exercise countermeasures: effects on human muscle protein dysregulation. Proteomics 2010; 10: 3756-74.

16. Zoll J, Ponsot E, Dufour S, et al. Exercise training in normobaric hypoxia in endurance runners. III. Muscular adjustments of selected gene transcripts. J Appl Physiol 2006; 100: 1258-66.

17. Matsushita M, Matsui $H$. Protein transduction technology J Mol Med 2005; 83: 324-8.

18. Innocenti A, Scozzafava A, Parkkila S, Puccetti L, De Simone G, Supuran CT. Investigations of the esterase, phosphatase, and sulfatase activities of the cytosolic mammalian carbonic anhydrase isoforms I, II, and XIII with 4-nitrophenyl esters as substrates. Bioorg Med Chem Lett 2008; 18: 2267-71.

19. Schaller B, Graf R. Cerebral ischemia and reperfusion: the pathophysiologic concept as a basis for clinical therapy. J Cereb Blood Flow Metab 2004; 24: 351-71. 